\title{
Optimum Nutrition by Optimum Digestion: A Unique Phenomena of Ayurveda
}

\author{
Sudhir Joshi* \\ District Ayurved Officer, District Panchayat, Vadodara, Government of Gujarat, India
}

*Corresponding author: Sudhir Joshi, District Ayurved Officer, District Panchayat, Vadodara, Government of Gujarat India

\begin{tabular}{lll}
\hline ARTICLE INFO & & ABSTRACT \\
\cline { 1 - 2 } $\begin{array}{l}\text { Received: 幽 April 19, } 2021 \\
\text { Published: 幽 May 04, } 2021\end{array}$ & & $\begin{array}{l}\text { Citation: Sudhir Joshi. Optimum Nutrition by Optimum Digestion: A Unique Phenomena } \\
\text { of Ayurveda. Biomed J Sci \& Tech Res 35(3)-2021. BJSTR. MS.ID.005718. }\end{array}$ \\
\hline
\end{tabular}

\section{Opinion}

Malnutrition has been imposing serious threat to the mankind since ages and even in today's era we are yet to conquer it. Medical science has done a lot for resolving this issue but still a lot needs to be done. Ayurved can be of great help in resolving this problem. But it needs to be admitted that Ayurved has a very different viewpoint for this problem. Ayurved stresses more on digestion then on nutrition and it also takes into consideration various factors like family trait, racial trait, indigenous trait etc while assessing the malnutrition.

As per modern science each dietary article has a fixed calorie and nutritive value. But it's hard to see that each person gets same nutritive and calorie value from the same dietary food article. This variation occurs due to below mentioned factors described as Aahar Parinamkar Bhaav in Ayurved which literally means factors that are responsible for the transformation of the ingested food. They are Ushma, Vayu, Kleda, Sneha, Kaal and Samyoga. Digestion and assimilation are a very complex process, and their perfect accomplishment is must for appropriate nutrition. These six factors can be of great help in realization of this process. Let us have a brief view of these factors.

\section{Ushma}

It is the main force behind appropriate digestion and absorption of any diet article. In its absence any type of food becomes useless for the body. At this juncture we need to relook at our concept of nutrition. Any food material that is having a fixed amount of calorie does not have same effect in all individuals. A pig that ingests waste material is no less healthy than an animal ingesting highly nutritious food. It is because of the fact that pig has an intrinsic mechanism that can break the available proximate principles and resynthesize the needed elements from it. The governing force behind this is Ushma. When we speak about malnutrition it's not always about lack of dietary substances, its more about lack of inherent capacity of breaking and resynthesizing the available food source. Any measure taken without considering this factor will fail in solving the problem of malnutrition.

\section{Vayu}

It is the principal force behind the movement of dietary elements in the alimentary canal. Digestion is a complex and staged process. Error at one stage due to Vayu may hinder further processing and this is frequently seen in persons who seem malnourished. Whenever we are there to rectify malnutrition we need to keep this factor in mind otherwise we may not get desired result even with best medicines or food articles.

\section{Kleda}

Kleda literally means the watery component. Digestion is a chemical process, and any chemical reaction needs a medium. The water content of digestive enzymes, water we ingest are essential for proper digestion and nutrition. As per Ayurveda minimal water should be taken while taking food. Water taken before or after the meals is not advisable. Few sips taken during eating is ideal. Any deviation from this habit may lead to indigestion and thus to malnutrition.

\section{Sneh}

It literally means fat. Fat is consumed either in form of gheeclarified butter or oil. Today we have considered ghee and oil as 
major culprit of obesity, hypertension etc and because of that its use has being restricted. But as per Ayurved sneh-fat is essential for the body. Acharya Sushrut has said Sneh saaroyan hi purushah i.e men is essentially essence of sneh-fat. We need to take appropriate amount of Sneh for proper transformation of the ingested food.

\section{Kaal}

Kaal means the time factor. It is the most underestimated factor while addressing nutritional problems. In Ayurved Kaal Bhojan is considered as the most beneficial habit for health. Unfortunately, we seldom give the needed importance to the habit of timely eating. If we give apt importance to the habit of eating at regular timings then many nutritional problems could be rectified.

\section{ISSN: 2574-1241}

DOI: $10.26717 /$ BJSTR.2021.35.005718

Sudhir Joshi. Biomed J Sci \& Tech Res

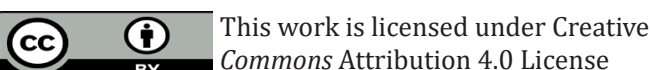

Submission Link: https://biomedres.us/submit-manuscript.php

\section{Samyog}

Samyog is synergistic effect of all the above factors. If due attention is given to all the factors and if all the actors are present then the collective effect will surely be compounded. It would be a boon for millions of people suffering from nutritive disorders if the above factors are put into their knowledge. Apart from the calorie value and nutritive value of any dietary article the above factors are far more important for tapping optimum nutrition from any food article.

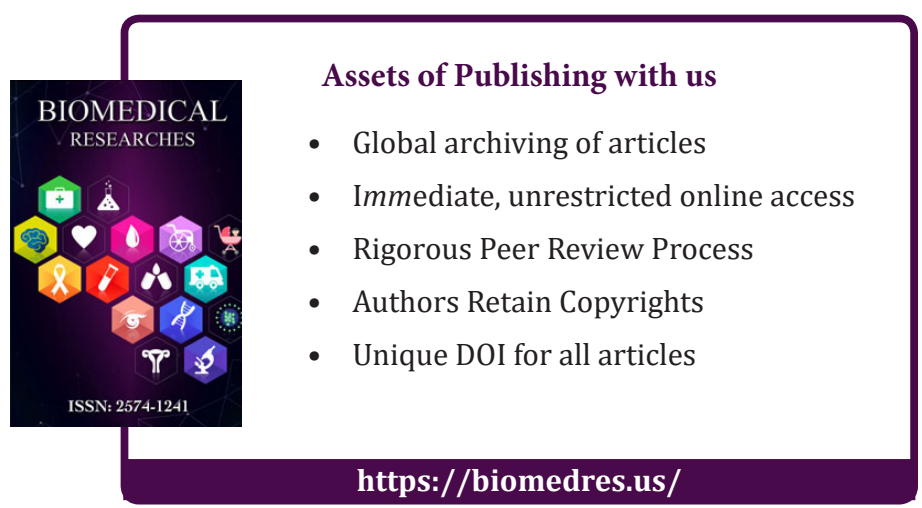

